\title{
Computer Competence of School Teachers
}

\author{
Dr. Jyoti Bhalla \\ Completed Ph. D. (Education) in Nov. 2011 from Department of Educational Studies, Faculty of Education, \\ Jamia Millia Islamia, New Delhi 110025, India
}

\section{Introduction}

Computer technology has opened wide opportunities for teachers to integrate computers in teachinglearning process. Computers greatly facilitates teaching-learning process for various curricular subjects especially language, mathematics and science. Computer technology is also being increasingly applied in noninstructional (record keeping, grade averaging, communication, etc.) and pre-instructional (developing materials, researching instructional content, etc.) uses. Various educationistshaveinterrelated computer use with constructivist, collaborative, and inquiry-based learning and also,withpedagogical change.

Studies carried out around the world in various industrialized as well as information-based countries have affirmed time and again that computer technology on its own shall never be able to substitute teachers and teachers shall always remain the principal actors who will facilitate harnessing the true potential of computer technology in education. Hence, it is important for teachers to become computer literate, and be prepared to use information technology in schools. Being prepared to adopt and use technology and knowing how that technology can support student learning must become integral skills in every teacher's professional repertoire. Various initiatives, mandates, recommendations put-froth by different government organizations, policies, have definitely served as catalysts to motivate school teachers in this direction. Various developing countries are currently following in the footsteps of the developed countries in promoting use of technology in education. In India, in association with the Global e-Schools and Communities Initiative (GeSCI), the Ministry of Human Resource Development (MHRD) has formulated India's National Policy on Information and Communication Technology (ICT) in School Education in order to devise, catalyze, support, and sustain ICT activities and processes to improve access, quality and efficiency of ICT tools and resources to all students and teachers. It promotes networking, research, evaluation and experimentation in ICT tools and practices to utilize the potentials of ICT in school education. Moreover, under Public Private Partnership model in education, various technology firms such as, Intel India, Microsoft Partners in Learning, Oracle Education Foundation are partnering with governments, educators, and local content and curriculum providers to create sustainable educational programs to train teachers and prepare students to succeed in the global economy.

Despite several initiatives and significant efforts in various developing countries, integration of computer technology in education still has a long way to go. Inspite of the growing support for computers as tools for teaching and learning,it has often been observed that there is a general unwillingness among teachers and schools to promote use of computers across the curriculum (Lidtke, 1979; Russek, 1991; Dawes and Selwyn, 1999; Harris, 2000; and Neiderhauser and Stoddart, 2001).Moreover, computer technology availability should not be mistaken for technology adoption and use. As noted by Baylor and Ritchie (2002), "regardless of the amount of technology and its sophistication, technology will not be used unless faculty members have the skills, knowledge and attitudes necessary to infuse it into the curriculum". A large part of this problem is the result of not having the knowledge of or expertise with computer-based instruction (Okinaka, 1992). Albirini (2004) confirmed in his study that teachers' computer competence predicted their positive attitudes toward technology in education. However, other researchers have concluded that although teachers may have positive attitudes toward technology (Duane \& Kernel, 1992; Office of Technology Assessment, 1995), they may still not consider themselves qualified to teach with it or comfortable using it.A number of studies have shown that teacher's lack of confidence (Winnans and Brown, 1992; Fisher, 1996; Morton, 1996 Fairbrother and Kurina, 2000; Pelgrum, 2001 Aduwa-Ogiegbaen and Iyamu, 2005) is one of the major obstacles in implementation of computers in teaching-learning process.

It is reasonable to hypothesize that integration of computer technology in education requires much more than mere computer-related skills. In this direction, Berger and Carlson (1988) criticized the concentration on technical competency and suggested that teachers should focus on learning and instructional-design theories as well as integrating computers into the curriculum. Teachers should be able to confidently use and evaluate a range of software packages and understand how the use of information technology changes the pedagogy (Davis, 1992). A study conducted by Guha (2000) revealed that teachers wanted to be competent in using computers in instruction as they could see positive changes in teaching strategies as a result of using this technology. Now the question arises what actually constitutes computer competence? Evidently, several studies 
that have been conducted worldwide to investigate measures for promoting integration of computer technology in education clearly emphasize the importance of computer competence, but the assessmentthereof has not been dealt with in an appropriate manner. Unfortunately, there is little consensus in the present literature as to what constitutes computer competence. Therefore, one of the key hurdles in enhancing teachers' computer competence levels in India as well as in other developing countries is lack of sufficient research in this direction. In the absence of acomprehensiveframework for assessing teachers' computer competence it is neither possible to assess current levels of teachers' computer competence nor is it possible to design suitable remediation plans. The need to assess computer competence assume much greater significance in the context of developing countries currently going through early stages of technology implementation in education. Understandably, the lack of appropriate measures to address the fundamental need of assessment of computer competence will continue to jeopardize effective integration of computer technology in education.

In light of this, there is a need for designing a comprehensive framework for defining and understanding computer competence of teachers. Such framework should prescribe essential dimensions of computer competence with regard to teachers' use of computers in teaching-learning process. Importantly, such framework should be readily adaptable to specific national contexts. The framework should provide such tools that facilitate systematic and comprehensive assessment of current level computer competence of teachers. It will be readily apparent that once such a framework is formulated, it could prove to be an indispensable instrument in designing measures for professional development of teachers for capacity-building in technologypedagogy integration, development of training modules, for excellence in teacher training in using computer technology for improving educational quality.

The current study was based on this vital need.

\section{Review}

This section looks at the various definitions of computer competence, a framework for constituents of computer competence, as well as prior researches on computer competence.

\subsection{Definitions of Computer Competence}

A number of definitions for the term "computer competence" can be found in the literature. In the earlierdays of this type of research, the term "computer literacy" was used rather thancomputer competence. The first definitions to appear in the literature identified computer literacy as an understanding of hardware and software or familiarity with computer programming languages. Similarly, it has been defined as knowledge of computer characteristics, capabilities, and applications, as well as the user's ability to implement this knowledge skillfully and productively (Simonson, Mauere, Monta-Toradi, and Whitaker, 1987). Anderson and Klassen(1981) suggested that computer literacy encompasses of understanding, skills and attitudes that are needed to perform a social role that directly or indirectly involves computers. Similarly, Watt (1980)defined computer literacy as that collection of skills, knowledge, understandings, values and relationships that allow a person to function comfortably as a productive citizen in a computer-oriented society. Thus, computer literacy refers to the ability to understand and to use computers. Most computer literacy instruction incorporates three types of objectives-knowledge (of terms, components, applications, social ethical issues), skill (word processing, spreadsheet, information retrieval, desktop publishing, problem solving), and attitude (acceptance as a valuable tool, appreciation as a productive tool).

National Policy on ICT in School Education, MHRD, India (2009, revised 2012) presents three stages of ICT literacy that constitute set of competencies for students and teachers: Basic level includes operate a computer, manage data, word and data processing tasks, troubleshoot basic storage, use input output devices, email - web surfing - search engines, anti virus, operate- manage content from external devices (sound recorders, digital cameras, scanners etc.); Intermediate level includes create - manage content using software applications, use digital devices, websites, search engines; Advanced level includes database applications, use of ICT for problem solving, audio-video communication, research, documentation, presentation, cooperative collaborative learning, cyber - copyright issues. These levels or stages constitute set of competencies for teachers and students.

\subsection{FrameworkforComputer Competence - What Constitutes Computer Competence}

In Morton's study (1996), a marked dichotomy was found between faculty members with differing amounts of computer knowledge. He found "Low tech" teachers engaged in more traditional pedagogical practices and found it more difficult to assimilate computers into their teaching style. "High tech" teachers, by contrast, integrated computers into their pedagogical practices readily. Beigel (1996) identified some computer competencies for educators as (1) evaluating and matching appropriate software to a learner's skills and abilities, (2) helping students use the computer as a personal productivity tool, (3) assessing individual needs, and (4) integrating technology into multiple environments. 
The Curriculum Guide and Syllabus for Information Technology in Schools (2001)developed by NCERT, India suggested that teachers would define their information technology literacy and competence by achieving mastery of skills in application of technology tools in support of learning, communication, research, problem solving and decision-making. This would enable the teacher to understand, plan, design, use, assess, computer-technology incorporated teaching-learning strategies; to enhance own skills; to consider legal ethical issues; to use constructivist, interdisciplinary, integration approach; by incorporating computer technology. Also, the teacher has to developachecklist for evaluation of learning materials in the context of (a) learner profile, (b) learning environment, and (c) technical strength of the computer laboratory of the school. Moreover, the teacher would review software to be procured and report the same to the principal so a purchase decision can be made.

To better prepare pre-service candidates for teaching in the information age, the International Society for Technology in Education (ISTE) has defined National Educational Technology Standards (NETS) (2002) to guide technology integration into teacher education programs. These include dividing the teachers' application of technology in instruction into six categories:technology related - understanding, designing of experiences, implementation of curriculum plans, assessment strategies, enhancement of productivity, legal-ethical issues.

The UNESCO implemented Beijing workshop (2003) on Teacher Training in ICT Integration discussed guidelines for developing Competency Based Standards for Teacher Education Curriculum which comprised of core competencies related to pedagogy (new ways of doing things with ICT; new theories of learning; pedagogical skills: selection, presentation and assessment), technology (related concepts and operations; social, health, legal and ethical issues) and technology-pedagogy integration (ethical, legal use of technology to design effective learning experiences; manage students' learning; improve professional skills; support interaction in learning/social communities).

\subsection{Prior Researches on Computer Competence}

Wells and Anderson (1995) reported that teachers initially focused on their own interaction with the new medium and as they gradually became comfortable with the technology they started deliberating upon potential learning benefits that would result from the use of the computer. Myhre (1998) concluded that increased familiarity with computers allowed teachers to turn their interest in the pedagogical use of technology (rather than its operational issues) but also emphasized that such change processes did not occur rapidly and were not easily achieved.Results of Halpin (1999) study on preservice teachers in San Diego, CA, indicated that the integration of computer literacy in method courses provided prospective teachers' confidence to transfer their computer skills into their classrooms based on their own explanatory experiences.

In a nationwide study of 608 teachers described as accomplished at integrating computing into their teaching by the Bank Street College of Education, New York (Hadley and Sheingold, 1993), it was concluded that, "provided there is enough technology for teachers to have regular access, ample support and time for teachers to learn how to use and plan for computer use and there is a school climate which encourages an experimental approach to teaching, then it is possible for other teachers to gain the expertise and comfort levels demonstrated by exemplary teachers". Akif and Akdemir (2008) investigated Turkey primary school science teachers' use of computer applications. Results demonstrated that improving the computer literacy of science teachers seems to increase science teachers' computer use and consequently increase their integration of computer applications as an instructional tool. Internet, email, and educational software CDs found to have high percentage in teachers' use of computer applications in the classrooms.

Angeli (2004) of Cyprus, explored transforming a teacher education method course through technology effects on preservice teachers' technology competency. The result indicated that the risk of preparing prescience teachers to become technology competent was difficult and required many efforts for providing them with ample of opportunities during their education to develop the competencies needed to be able to teach with technology in their classes. In a similar research by Brinkerhoff (2006), the effects of a long-duration, professional development academy on technology skills, computer integration beliefs and practices were studied and the results reported significant gains in participants' self-assessed technology skills and computer selfefficacy, with little or no change to self-assessed technology integration beliefs and practices.

The study by Russell, Finger and Russell (2000) aimed at establishing baseline information about Australian teachers' experience and skills in information technology. The investigation revealed that teachers saw themselves as competent with basic computer skills but were less confident with activities requiring advanced use of computers. In a survey conducted by Ely (1993),Pelgrum (2001),Aduwa-Ogiegbaen and Iyamu (2005) teachers' lack of knowledge/skills in computer use was one of the major reasons the unsuccessful implementation of computers in schools. Similarly, Jones (2004) reported that a very significant determinant of teachers' levels of engagement in ICT was their level of confidence in using the technology. 


\section{Study}

Given the importance of teachers' computer competencies to the successful infusion of computers into the curriculum, the purpose of the study was therefore to design a comprehensive framework for understanding computer competence of teachers, and use this framework to study teachers' current computer competence in all the related areas.

While the state of educational infrastructure and several other pertinent factors vary drastically across various schools in private, public and state government school systems in different regions of the country, KendriyaVidyalayas, owing to inherent design, mission, and objectives, maintain considerable uniformity in various establishments across the country. Hence, from the perspective of the present study, KendriyaVidyalayas provided as ideal population. The implications of the study could be generalized to design recommendations for formulating policies and strategies at a national and international level.

In the present study, the term computer means a device which is used for instructional as well as preinstructional and non-instructional purposes by teachers and students in teaching-learning process. The term "use of computers" (or "computer use") includesuse of computers in both instruction and management of the teaching-learning process.Computer competence is defined as specific computer skills or knowledge, demonstrated through performance which shows that a teacher has reached defined standards for a particular level of performance (Beijing workshop, 2003). According to the empirical data on competence of a teacher in use of computers, for the present study the computer competence is operationalized to include teacher perceived confidence in three areas namely, pedagogy, technology and integration of pedagogy and technology.

\subsection{Pedagogical Competencies}

The basic premise to begin the definition of pedagogy is: 'any conscious activity by one person designed to enhance learning in another'. Pedagogy, therefore, describes the collected practices, processes, strategies, procedures, and methods of teaching and learning. Examples related to the pedagogical competencies are presented in figure 1.

\begin{tabular}{|c|c|}
\hline Pedagogical Competencies & Demonstrated through Activities \\
\hline analyzing objectives & $\begin{array}{l}\text { selecting computer tools and pedagogy appropriate to individual student's } \\
\text { instructional objectives }\end{array}$ \\
\hline exploring content & $\begin{array}{l}\text { choosing computer tools and pedagogy that integrate computers into whole } \\
\text { curriculum }\end{array}$ \\
\hline assessing learners & $\begin{array}{l}\text { picking computer tools and pedagogy to assess diverse needs of a variety of } \\
\text { students in a heterogenous class }\end{array}$ \\
\hline discovering tasks & $\begin{array}{l}\text { seeking contribution of ICT that allow teacher and students to manage their own } \\
\text { learning and to improve their quality of work }\end{array}$ \\
\hline $\begin{array}{ll}\text { determining } & \text { teaching- } \\
\text { learning strategies }\end{array}$ & $\begin{array}{l}\text { planning an integrated learning programme that allows a range of computer tools } \\
\text { and pedagogy to be used as and when required }\end{array}$ \\
\hline evaluation & $\begin{array}{l}\text { deciding computer tools and pedagogy to assess performance levels of students as } \\
\text { well as teacher }\end{array}$ \\
\hline
\end{tabular}

Figure 1.Competencies in pedagogy for school teachers

\subsection{Technological Competencies}

Technology competency must not be understood solely in terms of hardware and software. Technology competencies help teachers access, gather, present and communicate, and manipulate the information that is available on software and internet resources, in the form of text, images, sound, etc. Examples related to the technological competencies are presented in figure 2 .

\begin{tabular}{|l|l|}
\hline $\begin{array}{l}\text { Technology } \\
\text { romnetencies } \text {.Use }\end{array}$ & Demonstrated through Activities \\
\hline $\begin{array}{l}\text { windows operating } \\
\text { system }\end{array}$ & select icons, choose menu options, use scroll bars, use toolbars, use help. \\
\hline plug-ins & $\begin{array}{l}\text { to extend the capability of the browser to access audio, video, animation or other } \\
\text { resources. }\end{array}$ \\
\hline projector & operate, use display options, adjust. \\
\hline printer & attach a printer, use options, page, copies, zoom. \\
\hline scanner & picture or text converted into a graphics image. \\
\hline digital camera & take pictures, store on computer. \\
\hline word program & $\begin{array}{l}\text { insert text, insert pictures, insert tables, delete, copy, cut, paste, drag and drop, } \\
\text { find/ replace, undo, redo, save as, print, track changes. }\end{array}$ \\
\hline presentation program & $\begin{array}{l}\text { create story board, open slide, view menu, toolbars, options, click, insert, menu, } \\
\text { slide order, slide transition, slide show, custom animation, record narration, } \\
\text { rehearse timings. }\end{array}$ \\
\hline spreadsheet program & $\begin{array}{l}\text { insert text, delete, copy, cut, paste, drag and drop, find and replace, undo and } \\
\text { redo, save, save as, print, formula, charts and graphs. }\end{array}$ \\
\hline
\end{tabular}




\begin{tabular}{|l|l|}
\hline database program & search for information, add information to a database, print information. \\
\hline graphics program & $\begin{array}{l}\text { capture, insert, display, manipulate, generate visuals, sounds, pictures, images, } \\
\text { illustrations. }\end{array}$ \\
\hline publisher program & $\begin{array}{l}\text { by wizard, brochures, personal information, customer address, organization, title, } \\
\text { zoom, product service information, headings, text frames, tools menu, format, } \\
\text { browse, pictures. }\end{array}$ \\
\hline new software & storage capacity, store on a computer, install, run. \\
\hline CD-roms/DVD & $\begin{array}{l}\text { play, save, transport information, disk handling, locate files on a disk, back-up } \\
\text { copies }\end{array}$ \\
\hline computer files and & $\begin{array}{l}\text { create, retrieve, open, use, save, edit, search, copy, delete, rename, view, arrange } \\
\text { icons, print. }\end{array}$ \\
\hline CD/USB devices & $\begin{array}{l}\text { burn, save, store and transfer data and information, use, safely remove, aware of } \\
\text { speed, storage capacity. }\end{array}$ \\
\hline world wide web & $\begin{array}{l}\text { connect to internet, navigate websites, use search engines, hyperlinks, save as, } \\
\text { send, use favourites. }\end{array}$ \\
\hline internet & $\begin{array}{l}\text { asynchronous/synchronous communication, mail groups, news groups, blogs, } \\
\text { chat, audio/video conferencing, e-mail (open, delete, new message, send, } \\
\text { attachments, address book, distribution list). }\end{array}$ \\
\hline trouble-shooting & $\begin{array}{l}\text { problems related to hardware connectivity, operating system incompatibility, } \\
\text { program operation, interfacing with peripherals, disk and hardware maintenance. }\end{array}$ \\
\hline antivirus programs & $\begin{array}{l}\text { configure virus protection software to protect system, download, update, scan } \\
\text { disks }\end{array}$ \\
\hline copyright material & $\begin{array}{l}\text { follow Net etiquette, avoid plagiarism, check conditions for use of content } \\
\text { published on WWW before copying any information. }\end{array}$ \\
\hline responsibly & $\begin{array}{l}\text { restrain from unauthorized intrusion, manipulating others' data, hacking, use } \\
\text { equipment properly so that it is not damaged. }\end{array}$ \\
\hline
\end{tabular}

Figure 2.Competencies in technology for school teachers

\subsection{Competencies in Integration of Pedagogy and Technology}

The term integration refers to a combination of technology and traditional teaching procedures to produce student learning. It comes with a willingness to combine technology and teaching into a productive experience that moves the learner to new understanding. Integrating technology in education for teaching-learning is not simply a matter of acquiring competency in technology alone, nor in pedagogy, nor even a combination of the two. Rather competencies of integration are about appropriate selection, use, fusion and integration of many sets of competencies, including, but not exclusive to, those in pedagogy and technology. These competencies are creating a new environment where learners are in control of their own learning needs and habits. In the Beijing workshop (2003) it was suggested that the competencies of integration involve processes of adding, mixing, amalgamation, assimilation, fusion, synthesis. This can be embedded throughout all subject areas, and all learning styles. The analogy of milkshake presented in figure 3, illustrates the spirit of integration of technology and pedagogy.

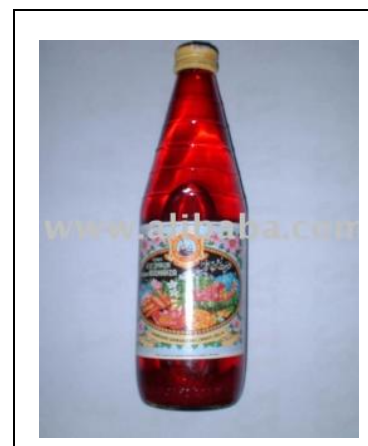

RoohAfza syrup Technology

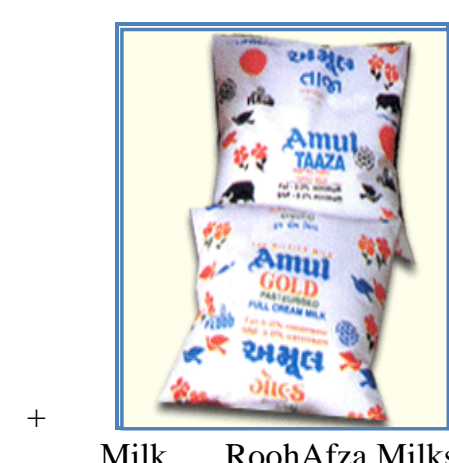

Milk RoohAfza Milkshake

Pedagogy Integration of Technology \& Pedagogy

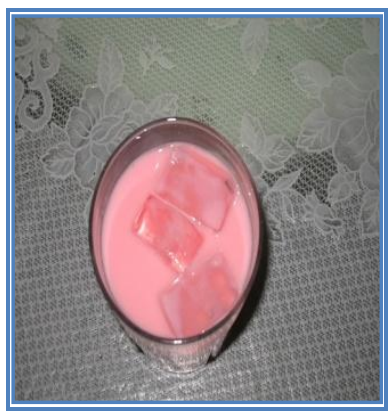

Figure 3.Integration of pedagogy and technology 
Examples related to the integration of technology and pedagogyare presented in figure 4.

\begin{tabular}{|c|c|}
\hline Integration Competencies : use computers & Demonstrated through Activities \\
\hline in teaching-learning & match computer technology with the curriculum needs. \\
\hline $\begin{array}{l}\text { to update subject knowledge and teaching } \\
\text { skills }\end{array}$ & $\begin{array}{l}\text { search on the internet to access information on instructional resources } \\
\text { (model lesson plans, on-line libraries and periodicals) and network with } \\
\text { experts, professionals for active collaboration. }\end{array}$ \\
\hline to prepare instructional material & $\begin{array}{l}\text { study guides, worksheets, hand-outs, manuals, announcements, puzzles, } \\
\text { banners, visuals, flowcharts, diagrams, scanned photographs, drawings, } \\
\text { slides for viewing on computer screen, for projecting, or for use in printed } \\
\text { form. }\end{array}$ \\
\hline $\begin{array}{l}\text { to support content learning in the } \\
\text { classroom }\end{array}$ & $\begin{array}{l}\text { regular classroom/lab instruction is complemented by use of a computer } \\
\text { with an overhead projector, a television, or any display device to display } \\
\text { graphical/pictorial/audio-video information to the whole class. }\end{array}$ \\
\hline $\begin{array}{l}\text { for project-based collaborative learning } \\
\text { activities }\end{array}$ & $\begin{array}{l}\text { plan and design effective learning environment with necessary technology } \\
\text { support for constructivist learning. }\end{array}$ \\
\hline $\begin{array}{l}\text { for assigning tasks to students that require } \\
\text { them to use computers }\end{array}$ & $\begin{array}{l}\text { information searches using internet/electronic encyclopedias/databases and } \\
\text { use of computer applications (word processing, spreadsheets, presentation, } \\
\text { or publisher software) for preparation of report/assignment/presentation. }\end{array}$ \\
\hline $\begin{array}{l}\text { to help students get access to right kind of } \\
\text { computer based instructions }\end{array}$ & $\begin{array}{l}\text { instruction in which a student directly interacts with a computer, locate } \\
\text { information from WWW, learn through lessons programmed into the } \\
\text { computer: tutorial, drill-and-practice, simulation, instructional gaming, } \\
\text { problem solving. }\end{array}$ \\
\hline $\begin{array}{l}\text { to prepare tools and techniques for } \\
\text { students' evaluation }\end{array}$ & $\begin{array}{l}\text { build question banks, prepare tests, administer tests (online/offline), } \\
\text { evaluate scripts (answer-sheets), store standardized test results, grades, and } \\
\text { monitor student progress }\end{array}$ \\
\hline for record keeping & students' attendance, assignments, grades, profiles \\
\hline $\begin{array}{l}\text { to share information with professionals, } \\
\text { parents or students }\end{array}$ & $\begin{array}{l}\text { through email, mail-base, bulletin board, school intranet, internet, } \\
\text { video/computer conferencing to report and share information regarding } \\
\text { student grades, to publish homework, feedback on homework, student's } \\
\text { progress report, classroom activities, etc. }\end{array}$ \\
\hline $\begin{array}{l}\text { to design personalized learning } \\
\text { experiences }\end{array}$ & $\begin{array}{l}\text { meeting diverse needs of a variety of students in the class by diagnosing } \\
\text { student's strength \& weaknesses, accordingly prescribe a study plan based } \\
\text { on student data (background, interests, test scores) and teacher's input } \\
\text { (available materials, alternative sequences, time available) }\end{array}$ \\
\hline to evaluate the usefulness of software & $\begin{array}{l}\text { content accurate, educational value, information well organized, level of } \\
\text { difficulties appropriate, provides 'hands-on' experiences, compatible, ease } \\
\text { of operation, user manual/follow-up activities/worksheets provided. }\end{array}$ \\
\hline $\begin{array}{l}\text { to adapt instructional software to the } \\
\text { curriculum needs }\end{array}$ & $\begin{array}{l}\text { certain students may receive computer based instruction either for } \\
\text { enrichment to catch up with the rest of the class. }\end{array}$ \\
\hline write courseware for lessons & $\begin{array}{l}\text { programming, authoring, writing educational programs according to the } \\
\text { syntax of programming languages like BASIC, LOGO. }\end{array}$ \\
\hline
\end{tabular}

Figure 4.Competencies in integration of pedagogy and technology

\subsection{Sample}

\section{Method}

To begin with, the researcher obtained the latest directory of KendriyaVidyalayas (Delhi Region, India) from the office of KendriyaVidyalayaSangathan, Delhi Region.From the list of KendriyaVidyalayas, a random sample of 20 schools was selected to participate in the study. From each of the selected school, 15 teachers were selected randomly from the teachers' attendance register such that preferably a set of 5 teachers (excluding computer teachers) was selected from each of the three grades (PRT, TGT and PGT grade). Thus, a total number of 300 teachers of KendriyaVidyalayas of NCT of Delhi constituted sample of the present study.

\subsection{Construction of Questionnaire}

An initial questionnaire was submitted to the experts for face and content validity. In case of 'yes - no' type validity assessment, an item in the questionnaire was accepted if more than half of the experts provided affirmative responses.As such, for this questionnaire, since all the items related to computer competence were found valid by the experts, hence no item was deleted. Their suggestions to rephrase complex sentence constructions into simpler sentences were incorporated and a quasi-final draft was obtained to be administered on the try-out sample. In order to identify weak, ambiguous, non-functional, or defective items, the quasi-final questionnaire was administered for try-out to a sample of 30 teachers, 10 each from the three selected schools of Delhi. The resulting responses were statistically analyzed to determine the reliability of scale in the quasi-final questionnaire. The Cronbach's Alpha for 'competence of teachers in use of computers' was calculated to be 0.97 and found significant at $\mathrm{p}<0.01$ level (Table 1$)$ 
Table 1.Mean, SD, Reliability Coefficient for computer competence $(N=30)$

\begin{tabular}{llllll}
\hline Construct & N Items & Mean & $S D$ & $\alpha^{*}$ & \\
\cline { 1 - 5 } & Competence of Teachers & 45 & 2.31 & 0.25 & 0.97 \\
\hline * Signt at $\mathrm{p}<0.01$ level & & &
\end{tabular}

* Significant at $\mathrm{p}<0.01$ level

As the questionnairewas found to be quite reliable (Cronbach's Alpha=0.97), quasi-final questionnaire was used as the final questionnaire. Thus, the final 45-items questionnaire consisted of a 3-point scale to measure teachers' current competence level regarding computer technology (items 1-23), pedagogy (items 2430), and integration of pedagogy and technology (items 31-45).

\subsection{Administration of Questionnaire}

After seeking permission from the Assistant Commissioner, KendriyaVidyalayaSangathan and the Principals of respective schools, aquestionnaire(Appendix 1)was given to each selected teacher in the free periods. The teachers were given three days to fill-in the questionnaire as per the instructions provided therein and the filled-in questionnaires were collected from the teachers on the agreed dates.

\subsection{Analyses of Data}

The mass of data gathered through the survey questionnaire was analyzed using Statistical Package for Social Sciences (SPSS) software and interpreted accordingly. Descriptive statistics were used to describe and summarize the properties of the data collected from the respondents.

\section{Results}

The teachers were asked to indicate their computer competence by encircling one number against each of the forty five statements on a three point scale: 1 = can't do (cannot accomplish under any circumstances), 2 $=$ with difficulty (can accomplish with assistance) and $3=$ comfortably (can accomplish confidently without any assistance). The final score of respondents on the scale was sum of their ratings for all of the items. The percentage of respondents in each of these categories was calculated and computer competence was represented by a mean score on a three-point, scale ranging from 1 (can't do) to 3 (comfortably) (Table2).

Table 2.Percentage distribution of respondents in computer competence and distribution of mean scores of responses on computer competence scale

\begin{tabular}{|c|c|c|c|c|c|}
\hline \multirow[t]{2}{*}{ Scale } & $\begin{array}{l}\text { Can't do } \\
1\end{array}$ & $\begin{array}{l}\text { With Difficulty } \\
2\end{array}$ & $\begin{array}{l}\text { Comfort-ably } \\
3\end{array}$ & \multirow{2}{*}{$\begin{array}{l}\text { Mean } \\
\text { Score }\end{array}$} & \multirow[t]{2}{*}{$S D$} \\
\hline & \multicolumn{3}{|c|}{ Percent (\%) } & & \\
\hline Technology & $21.80 \%$ & $30.51 \%$ & $47.69 \%$ & 1.37 & 0.48 \\
\hline Pedagogy & $13.90 \%$ & $41.66 \%$ & $44.44 \%$ & 1.33 & 0.51 \\
\hline Integration & $14.57 \%$ & $39.72 \%$ & $45.71 \%$ & 1.30 & 0.40 \\
\hline Overall Competence & $18.16 \%$ & $35.31 \%$ & $46.53 \%$ & 1.31 & 0.46 \\
\hline
\end{tabular}

As evident from the Table 2, the respondents had a mean score of $1.31(\mathrm{SD}=0.46)$ for their competence in use of computers. Therefore, on an average, teachers either could not use computers or could use computers with difficulty. Less than half of the teachers $(46.53 \%)$ had knowledge of computers and could comfortably use computers. More than two-thirds of the teachers $(35.31 \%)$ were found to be able to use computers with difficulty. Approximately, one-fifth of the teachers (18.16\%) were not at all able to use computers.

Less than half of the teachers $(47.69 \%)$ could handle basic computer functions needed by them comfortably. It is also indicated that one-fifth $(21.8 \%)$ and one-third $(30.51 \%)$ of the teachers either could not use technology or with difficulty respectively, including use of windows, projector, peripherals and Internet. Majority of teachers either could not plan and practice pedagogy (13.9\%) or could plan and practice with difficulty $(41.66 \%)$ that is they could not organize a whole learning program that allowed integration of computers into curriculum as and when required. One-fifth of the teachers $(14.57 \%)$ were not able to integrate technology with pedagogy and two-fifth of the teachers $(39.72 \%)$ could do it with difficulty.

Furthermore, the 45 item-wise percentages of three categories of responses (can't do, with difficulty and comfortably) on Computer Competence Scale are presented in Table 3.Technology: 1-23, Pedagogy: 24-30, Integration: 31-45. 
Table 3.Item-wise percentage distribution of respondents on computer competence scale

\begin{tabular}{|c|c|c|c|c|}
\hline \multirow[b]{2}{*}{ \# } & \multicolumn{2}{|l|}{ Statements } & \\
\hline & I can ... & $\overbrace{}^{\infty} \approx$ & 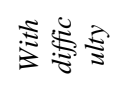 & 造 $\frac{1}{0} \frac{1}{8}$ \\
\hline 1 & use windows operating system & 2.3 & 25.7 & 72.0 \\
\hline 2 & adjust windows accessibility options & 10.3 & 36.3 & 53.3 \\
\hline 3 & use plug-ins & 13.3 & 34.0 & 52.7 \\
\hline 4 & use projector & 13.3 & 29.7 & 57.0 \\
\hline 5 & use printer & 14.3 & 28.3 & 57.3 \\
\hline 6 & use scanner & 24.7 & 40.3 & 35.0 \\
\hline 7 & use digital camera & 23.0 & 27.0 & 50.0 \\
\hline 8 & operate word processing program & 10.0 & 24.7 & 65.3 \\
\hline 9 & operate presentation program & 7.0 & 19.7 & 73.3 \\
\hline 10 & operate spreadsheet program & 19.0 & 49.3 & 31.7 \\
\hline 11 & operate database program & 30.0 & 42.0 & 28.0 \\
\hline 12 & operate graphics program & 45.3 & 35.7 & 19.0 \\
\hline 13 & operate publisher program & 51.3 & 33.3 & 15.3 \\
\hline 14 & install software & 43.0 & 32.7 & 24.3 \\
\hline 15 & use CD-ROMs/DVD & 8.0 & 18.0 & 74.0 \\
\hline 16 & create and organize computer files folders & 7.7 & 22.3 & 70.0 \\
\hline 17 & store and transfer data using CD/USB devices & 7.7 & 31.7 & 60.7 \\
\hline 18 & use www to access information sources & 8.7 & 19.3 & 72.0 \\
\hline 19 & use internet for communication & 9.3 & 23.7 & 67.0 \\
\hline 20 & use trouble-shooting strategies & 45.7 & 35.3 & 19.0 \\
\hline 21 & use antivirus programs and update them & 37.7 & 29.3 & 33.0 \\
\hline 22 & use copyright material available on internet & 25.0 & 31.7 & 43.3 \\
\hline 23 & practice responsible use of software/ & 44.7 & 31.7 & 23.7 \\
\hline 24 & $\begin{array}{l}\text { select computer tools and pedagogy that integrate computers into the } \\
\text { curriculum }\end{array}$ & 21.3 & 45.0 & 33.7 \\
\hline 25 & $\begin{array}{l}\text { select computer tools and pedagogy appropriate to the individual student's } \\
\text { instructional objectives }\end{array}$ & 22.6 & 46.9 & 30.6 \\
\hline 26 & select computer tools and pedagogy that allow me to manage my learning & 14.7 & 40.0 & 45.3 \\
\hline 27 & $\begin{array}{l}\text { select computer tools and pedagogy that allow my students to manage their } \\
\text { learning }\end{array}$ & 17.0 & 50.3 & 32.7 \\
\hline 28 & $\begin{array}{l}\text { guide students to use computer based instructions to enhance quality of their } \\
\text { creative work }\end{array}$ & 3.7 & 27.7 & 68.7 \\
\hline 29 & $\begin{array}{l}\text { justify the contribution of computers to raise the performance levels of } \\
\text { students }\end{array}$ & 4.3 & 29.0 & 66.7 \\
\hline 30 & $\begin{array}{l}\text { plan a whole learning programme that allows a range of computer tools and } \\
\text { pedagogy to be used }\end{array}$ & 13.7 & 52.7 & 33.7 \\
\hline 31 & match computer technology with curriculum & 12.3 & 40.3 & 47.3 \\
\hline 32 & update my knowledge and teaching skills using computers & 3.3 & 33.0 & 63.7 \\
\hline 33 & use computers to prepare instructional material & 9.7 & 30.0 & 60.3 \\
\hline 34 & use computers to support content learning & 4.3 & 30.3 & 65.3 \\
\hline 35 & use computers for project-based collaborative learning activities & 7.3 & 32.7 & 60.0 \\
\hline 36 & assign tasks to students that require computers & 6.7 & 30.7 & 62.7 \\
\hline 37 & help students get access to right kind of computer based instructions & 7.3 & 30.7 & 62.0 \\
\hline 38 & use computers to prepare tools and techniques for students' evaluation & 25.3 & 45.7 & 29.0 \\
\hline 39 & use computers to assess students' performance & 24.7 & 42.3 & 33.0 \\
\hline 40 & use computers for record keeping activities & 15.0 & 34.0 & 51.0 \\
\hline 41 & use internet to share information with professionals, parents or students & 13.0 & 31.3 & 55.7 \\
\hline 42 & use computers to design personalized experiences & 23.3 & 51.7 & 25.0 \\
\hline 43 & evaluate the usefulness of software for my lessons & 21.3 & 56.7 & 22.0 \\
\hline 44 & adapt instructional software to my curriculum needs & 20.7 & 55.7 & 23.7 \\
\hline 45 & write courseware for my own lessons & 24.3 & 50.7 & 25.0 \\
\hline
\end{tabular}

Some of the striking findings as evident in Table 3 reveal that half of the teachers lacked sufficient technological competence associated with use of scanner, digital camera, spreadsheet, database, antivirus, and 
copyright. About two-third of the teachers lacked competencies related to graphics, publisher, software installation, troubleshooting strategies, and responsible use of software/hardware by restraining from unauthorized intrusion, manipulation others' data and hacking.

Slightly more than half of the teachers lagged behind in the pedagogical competencies associated with selection ofcomputer tools and pedagogy that integrate computers in curriculum,that are appropriate to each individual student's learning-objectives, that allow their students to manage their learning, and also that allow them to manage their own learning for updating subject knowledge/skills.

In case of integration of technology and pedagogy, about two third of the teachers reported lack of competence in using computers for evaluationor assessment of students' performance, designing personalized learning experiences, evaluating or adapting instructional software to their curricular needs, and writing courseware for their lesson.

\section{Discussion}

A computer is not, and never will be, transformative on its own-it requires teachers who can integrate computer into curriculum and use it to improve student learning. The integration of computers in teachinglearning entails transformation of teaching process as well as redefining the role of teachers to a great extent.

Despite several efforts and initiatives by the government and non-government organizations in various developing countries, one of the key obstacles in effective integration of computers in education is the teachers' lack of knowledge and expertise with use of computers. Although researches to examine measures for promoting use of computers in education have emphasized the importance of teachers' computer competence but its know-how has not been dealt appropriately. Therefore, impediments like what constitutes teachers' computer competence and how it should be assessed need to be addressed before the power of computers is exploited to its full potential to transform teaching-learning process in the most effective manner. Hence, a need was felt to design a comprehensive framework for understanding teachers' computer competence. The study has provided such a framework that prescribesessential dimensions of teachers' computer competence with regard to their use of computers in teaching-learning process. The study has also used this framework in the form of a questionnaire to investigate the current level of teachers' computer competence. In the study computer competence included teacher perceived confidence in three areas namely, pedagogy, technology and integration of pedagogy and technology.

The findings indicated a mean score of 1.31 (on a 3-point scale) for competence of teachers in use of computers. The study showed that less than half of the teachers (46.3\%) could use computers in computerbased-instructions. More than half of the teachers were found to be able to use computers either with difficulty $(35.31 \%)$ or not at all $(18.16 \%)$. This deficiency of comfort while using computers in education has been reported in the literature also. Researchers have indicated that although teachers might have positive attitudes toward technology, they might still not consider themselves qualified to teach with it or be comfortable using it (Berger and Carlson, 1988; Davis, 1992; Duane and Kernel, 1992; Office of Technology Assessment, 1995; Odabasi, 2000; and Sadker and Sadker, 2003).

The teachers' lack of knowledge/skills in use of computers was considered as one of the major reasons for unsuccessful implementation of computers in teaching-learning process (Winnans and Brown, 1992; Ely, 1993; Fisher, 1996; Morton, 1996; Pelgrum, 2001; Aduwa-Ogiegbaen and Iyamu, 2005; Jones, 2004).In the present study as well, while integrating technology with pedagogy, teachers reported lack of competence in use of computers for evaluation and assessment of students' performance, designing personalized learning experiences, evaluating and adapting instructional software to their curricular needs and writing courseware for their lesson. Hence, it is important for teachers to be computer literate;to have sufficient knowledge, understanding, skill and attitude; and be prepared in order to integrate computers in teaching-learning process.

Indeed, researchers Russell, Finger and Russell (2000) have revealed that teachers saw themselves as competent with basic computer skills but were less confident with activities requiring advanced use of computers. The findings from the present study substantiate this. The study revealed that teachers lacked sufficient technological competence associated with use of scanner, digital camera, spreadsheet, database, antivirus, and copyright. Teachers further lacked competencies related to graphics, publisher, software installation, troubleshooting strategies, and responsible use of software/hardware by restraining from unauthorized intrusion, manipulation others' data and hacking.

Researchers Wells and Anderson (1995) Myhre (1998) Halpin (1999) (Hadley and Sheingold, 1993) Akif and Akdemir (2008) CharoulaAngeli (2004) have concluded that increased familiarity with computers allowed teachers to turn their interest in the pedagogical use of technology (rather than its operational issues) and also emphasized that such change processes did not occur rapidly and were not easily achieved. The present study supports and extends such knowledge in existing literature wherein teachers lagged behind in the pedagogical competencies associated with selection ofcomputer tools and pedagogy that integrate computers in curriculum, that are appropriate to each individual student's learning-objectives, that allow them to manage learning. 


\section{Conclusion}

Over past 20 years, the educational potential of computers has been explored by educationalists. Therefore, being prepared to adopt and use technology and knowing how that technology can support student learning must become integral skills in every teacher's professional repertoire. Within the framework of these changing roles, the responsibility for learning would fall more and more on the teachers. This constructivist approach demands competency in the newer pedagogies. Unfortunately, as a matter of fact, a vast majority of teachers use computers only for support in the educational practice while only a few teachers actually integrate computers as a teaching tool or learning device. Similar trends are emerging in many developing countries and the situation in India is no exception. Actually, one of the key hurdles in enhancing teachers' computer competence levels in India these countries is lack of sufficient research in this direction. In the absence of a comprehensive definition and an all-inclusive framework for assessing teachers' computer competence it is neither possible to assess current levels of teachers' computer competence nor is it possible to design suitable remediation plans which in turncontinue to imperil effective integration of computer technology in education.As present study was based on this vital need, the researcher attempted to design a comprehensive framework for understanding and assessing teachers' computer competence. Towards this end, researcher attempted to construct a questionnaire to assess teachers' computer competence in the form of teacher perceived confidence in all the three areas namely, pedagogy, technology and integration of pedagogy and technology. A detailedappraisal of the current levels of computer competence, as perceived by school teachers, would prove to be an indispensible instrument in designing measures for enhancing computer competence of teachers.

Although the study was conducted in the KendriyaVidyalayas of NCT of Delhi, the implications are applicable to various other government, public and private school systems existent in India and abroad.

The study has put forth various competencies wherein teachers lagged behind, such as pedagogical competencies like selection ofcomputer tools and pedagogy that integrate computers in curriculum, that are appropriate to each individual student's learning-objectives, that allow their students to manage their learning, and also that allow them to manage their own learning for updating subject knowledge and skills; technological competencies relating to graphics, publisher, software installation, troubleshooting strategies, and responsible use of software/hardware by restraining from unauthorized intrusion, manipulation others' data and hacking; integration competencies like using computers for evaluation and assessment of students' performance, designing personalized learning experiences, evaluating and adapting instructional software to their curricular needs and writing courseware for their lesson.

Thus, the study identifies several areas related to competence of teachers in use of computer which need special attention. As teachers' computer competence is a strong determinant of use of computers by teachers, it would be worthwhile to expend time and money in improving the competence level of teachers in various aspects related to use of computers in teaching-learning process. Based on the findings of the present study, it is recommended that there should be a continuous assessment of teacher's computer knowledge and skills to improve their competence in use of computers. In addition, it is recommended to initiate steps for mandatory implementation of computer-based content delivery; computerized pre- and non-instructional activities.The level of computer skills is needed to be continuously enhanced through regular trainings. The more skilled are the teachers in technology, pedagogy and integration of technology and pedagogy, the more would be the use of computers in teaching-learning process. Therefore, as competence of teachers in use of computers may be an important factor in determining use of computers, it is believed that an understanding of various competencies related to teachers' use of computers would empower the policy and decision makers with useful information to aid strategy formulation to implement widespread adoption of computer use in teachinglearning process.

\section{Acknowledgements}

I thank God for giving me courage to complete this paper. I consider it an honor to accomplishmy Ph.D. research work from the Department of Educational Studies, JamiaMilliaIslamia, Delhi, India. I would like to express my indebtedness for the participants and experts who have given me their precious time. I am grateful to my guide Prof. Najma Amin for her valuable suggestions. I wish to express my love and gratitude to my beloved husband Mr. PuneetBhalla and son Master UnnabhBhalla for their understanding and endless love, through the duration of mywork.

\section{References}

[1] Aduwa-Ogiegbaen, S. E., \&Iyamu, E. O. S. (2005). Using Information and Communication Technology in Secondary Schools in Nigeria: Problems and Prospects. Educational Technology \& Society, 8(1), 104-112. EBSCOhost.

[2] Akif\&Akdemir (2008). An Investigation of Primary School Science Teachers' Use of Computer Applications.ERIC Document Reproduction Service No. ED503471.

[3] Albirini, A. (2006). Teachers' attitudes towards information and communication technologies: the case of Syrian EFL teachers. Computers \& Education, 47, 373-398.

[4] Anderson, C. (1983). Computers literacy: Changes for teacher education. Journal of Teacher Education, 34(5), 6-9. EBSCOhost. 
[5] Angeli, C. (2005). Transforming a teacher education method course through technology: effects on preservice teachers-technology competency. Computers \& Education, 45, 383-398

[6] Baylor, A., \& Ritchie, D. (2002). What factors facilitate teachers skill, teacher morale, perceived student learning in technologyusing classroom?. Computers \& Education, 39, 395-414.

[7] Beigel, Andrew R. (1996). Developing Computer Competencies among Special Needs Educators. ERIC Document Reproduction Services No. EJ 521812.

[8] Berger, C., \& Carlson, E. (1988). A model for incorporating learning theories into preservice computer training. In M. Taylor (Ed.), Outlook (pp. 32-46). New York: Special Interest Group on Computer Uses in Education of the Association for Computing Machinery. EBSCOhost.

[9] Brinkerhoff, J. (2006). Effects of a long-duration, professional development academy on technology skills, computer self-efficacy, and technology integration beliefs and practices. Journal of Research on Technology in Education, 39(1), 22-43. EBSCOhost.

[10] Davis, F. D., Bagozzi, R. P., \&Warshaw, P. R. (1992). Extrinsic and intrinsic motivation to use computers in the workplace. Journal of Applied Social Psychology, 22, 1111-1132. EBSCOhost.

[11] Davis, N. (1992). Information technology in the United Kingdom initial teacher education, 1982-1992. Journal of Information Technology for Teacher Education, 1(1), 7-21. EBSCOhost.

[12] Dawes, L. \& Selwyn, N. (1999). Teaching with the dream machines: the representation of teachers and computers in IT advertising. Journal of Information Technology in Teacher Education, 8(3), 289-304. EBSCOhost.

[13] Ely, D. P. (1995). Technology is the answer! But what was the question? The James P. Curtis Distinguished Lecture, Capstone College of Education Society, University of Alabama. ERIC Service No. ED 381152.

[14] Fairbrother, R. \&Kurina, L. (2000). A study into the professional views and needs of science teachers in primary and secondary schools in England. London; King's College. EBSCOhost.

[15] Fisher, C., Dwyer, D., \&Yocam, K. (1996). Education and technology: Reflections on computing in classrooms. San Francisco: Jossey-Bass.

[16] Guha, S. (2000). Are we all technically prepared? Teachers' perspective on the causes of comfort or discomfort in using computers at elementary grade teaching. Atlanta, GA: The Annual Meeting of the National Association for the Education of Young Children. ERIC Document Reproduction Service No. ED 456101.

[17] Hadley, M., \&Sheingold, K. (1993). Commonalities and distinctive patterns in teachers' integration of computers. American Journal of Education, 101, 281-315. EBSCOhost.

[18] Halpin, R. (1998). Computer literacy taught through student-centered activities in elementary teacher education: constructivist theory put into practice. San Diego, CA: The National Educating Computing Conference. ERIC Document Reproduction Service No. ED 419498

[19] Harris, J. M. (2000). Utilization of computer technology by teachers at Carl Schurz High School, A Chicago Public School (Illinois), Dissertation Abstracts International, 61(6), 2268.

[20] International Society for Technology in Education. (2000). National educational technology standards for teachers. Eugene. http://cnets.iste.org/.

[21] Jones, A. (2004). A Review of the Research Literature on Barriers to the Uptake of ICT by Teachers. British Educational Communications and Technology Agency. Version 1. http://www.becta.org.uk

[22] Lidtke (1979) \& Madden (1989). In Krysa, R. (1998). Factors affecting the adoption and use of computer technology in schools. Educational Communications and Technology. http://www.usask.ca/education/coursework/802papers/krysa/ron.html.

[23] Morton, A. (1996). Factors affecting the integration of computers in Western Sydney secondary schools. Faculty of Education, University of Western Sydney, Nepean. http://www.ascilite.org.au/aset-archives/confs/edtech96/morton.html

[24] Myhre, O. R. (1998). I think this will keep them busy: computers in a teacher's thought and practice. Journal of Technology and Teacher Education, 6(2-3), 93-103. EBSCOhost.

[25] National Policy on Information and Communication Technology (ICT) in School Education. (2009). Department of School Education and Literacy Ministry of Human Resource Development Government of India. http://www.education.nic.in/secedu/ict.pdf

[26] NCERT. (2001). Curriculum Guide syllabus for information technology in schools NCERT. http://www.ncert.nic.in/html/itcurriculum.htm

[27] Niederhauser, D.S., \& Stoddart, T. (2001). Teachers' Instructional perspectives and use of education software. Teaching and Teacher Education, 17(1), 15 - 31. EBSCOhost.

[28] Okinaka, R. (1992). The factors that affect teacher attitude toward computer use. ERIC Document Reproduction Service No. ED 346039.

[29] OTA (1995). Teachers and technology: Making the connection, Washington, DC: Government Printing Office. http://fas.org/ota/technology_assessment_and_congress/houghton/

[30] Pelgrum, W. J. (2001). Obstacles to the integration of ict in education: Result from a world wide educational assessment. Computers \& Education, 37, 163-178.

[31] Russek, G. E., \& Weinberg, S. L. (1991). Mixed methods in a study of implementation of technology-based materials in the elementary classroom. ERIC Document Reproduction Service No. ED 335360.

[32] Russell, G; Finger, G and Russell, N (2000). Information Technology Skills of Australian Teachers: Implications for Teacher Education, Journal of Information Technology for Teacher Education, 9(2), 149-166. EBSCOhost.

[33] Sadker, P, M. \&Sadker, M. D. (2003). Teachers, school and society. New York: McGraw Hill.

[34] Simonson, M. R., Maurer, M., Monta-Toradi, M., \& Whitaker, M. (1987). Development of a standardized test of computer literacy and computer anxiety index. Journal of Educational Computing Research, 3(2), 231-247. http://ascilite.org.au/asetarchives/confs/aset-herdsa2000/procs/maguire.html

[35] UNESCO (2003). Implemented project on training and professional development of teachers/facilitators in the effective use of ICT for improved teaching and learning supported by Japanese funds-in-trust programmes Asia and Pacific regional bureau for education, UNESCO Bangkok, Beijing, China. September 27-29. http://unesdoc.unesco.org/images/0013/001356/135607e.pdf.

[36] Watt, D. H. (1980). Computer literacy: What should schools be doing about this? Classroom Computer News, 1(2), 1-26.

[37] Wells \& Anderson (1995). In Myhre, O. (1998). I think this will keep them busy: computers in a teacher's thought and practice. Journal of Technology and Teacher Education, 6(2-3), 93-103. EBSCOhost.

[38] Wells, J. G., \& Anderson, D. K. (1995). Teachers' stages of concern towards Internet integration (Report No. TAC B-459). ERIC Document Reproduction Service No. ED 389261.

[39] Winnans, C., \& Brown, D. S. (1992). Some factors affecting elementary teachers' use of the computer. Computers \& Education, 18(4), 301-309. 


\section{Questionnaire to study the computer competence of school teachers}

Instructions:Please indicate your current competence level regarding computer technology, pedagogy, and integration of pedagogy and computer technology by encircling one number against each of the following statements. Kindly consider the following explanations when rating your competence level.
1. Can't do cannot accomplish under any circumstances
2. With difficulty
can accomplish with assistance
3. Comfortably
can accomplish confidently without any assistance

\begin{tabular}{|c|c|c|c|c|}
\hline$\#$ & $\begin{array}{l}\text { Categories of Competence } \\
\text { I can ... }\end{array}$ & Can't do & $\begin{array}{l}\text { With } \\
\text { difficulty }\end{array}$ & Comfortably \\
\hline 1 & use windows operating system & 1 & 2 & 3 \\
\hline 2 & adjust windows accessibility options & 1 & 2 & 3 \\
\hline 3 & use plug-ins & 1 & 2 & 3 \\
\hline 4 & use projector & 1 & 2 & 3 \\
\hline 5 & use printer & 1 & 2 & 3 \\
\hline 6 & use scanner & 1 & 2 & 3 \\
\hline 7 & use digital camera & 1 & 2 & 3 \\
\hline 8 & operate word processing program & 1 & 2 & 3 \\
\hline 9 & operate presentation program & 1 & 2 & 3 \\
\hline 10 & operate spreadsheet program & 1 & 2 & 3 \\
\hline 11 & operate database program & 1 & 2 & 3 \\
\hline 12 & operate graphics program & $\mathbf{1}$ & 2 & 3 \\
\hline 13 & operate publisher program & 1 & 2 & 3 \\
\hline 14 & install software & 1 & 2 & 3 \\
\hline 15 & use CD-ROMs/DVD & 1 & 2 & 3 \\
\hline 16 & create and organize computer files folders & 1 & 2 & 3 \\
\hline 17 & store and transfer data using CD/USB devices & 1 & 2 & 3 \\
\hline 18 & use www to access information sources & 1 & 2 & 3 \\
\hline 19 & use internet for communication & 1 & 2 & 3 \\
\hline 20 & use trouble-shooting strategies & 1 & 2 & 3 \\
\hline 21 & use antivirus programs and update them & 1 & 2 & 3 \\
\hline 22 & use copyright material available on internet & 1 & 2 & 3 \\
\hline 23 & practice responsible use of software/ & 1 & 2 & 3 \\
\hline 24 & $\begin{array}{l}\text { select computer tools and pedagogy that integrate computers into } \\
\text { the curriculum }\end{array}$ & 1 & 2 & 3 \\
\hline 25 & $\begin{array}{l}\text { select computer tools and pedagogy appropriate to the individual } \\
\text { student's instructional objectives }\end{array}$ & 1 & 2 & 3 \\
\hline 26 & $\begin{array}{l}\text { select computer tools and pedagogy that allow me to manage my } \\
\text { learning }\end{array}$ & 1 & 2 & 3 \\
\hline 27 & $\begin{array}{l}\text { select computer tools and pedagogy that allow students to manage } \\
\text { their learning }\end{array}$ & 1 & 2 & 3 \\
\hline 28 & $\begin{array}{l}\text { guide students to use computer based instructions to enhance } \\
\text { quality of their creative work }\end{array}$ & 1 & 2 & 3 \\
\hline 29 & $\begin{array}{l}\text { justify the contribution of computers to raise the performance levels } \\
\text { of students }\end{array}$ & 1 & 2 & 3 \\
\hline 30 & $\begin{array}{l}\text { plan a whole learning programme that allows a range of computer } \\
\text { tools and pedagogy to be used }\end{array}$ & 1 & 2 & 3 \\
\hline 31 & match computer technology with curriculum & 1 & 2 & 3 \\
\hline 32 & update my knowledge and teaching skills using computers & 1 & 2 & 3 \\
\hline 33 & use computers to prepare instructional material & 1 & 2 & 3 \\
\hline 34 & use computers to support content learning & 1 & 2 & 3 \\
\hline 35 & use computers for project-based collaborative learning activities & 1 & 2 & 3 \\
\hline 36 & assign tasks to students that require computers & 1 & 2 & 3 \\
\hline 37 & help students get access to right kind of computer based instructions & 1 & 2 & 3 \\
\hline 38 & $\begin{array}{l}\text { use computers to prepare tools and techniques for students' } \\
\text { evaluation }\end{array}$ & 1 & 2 & 3 \\
\hline 39 & use computers to assess students' performance & 1 & 2 & 3 \\
\hline 40 & use computers for record keeping activities & 1 & 2 & 3 \\
\hline 41 & $\begin{array}{l}\text { use internet to share information with professionals, parents or } \\
\text { students }\end{array}$ & 1 & 2 & 3 \\
\hline 42 & use computers to design personalized experiences & 1 & 2 & 3 \\
\hline 43 & evaluate the usefulness of software for my lessons & 1 & 2 & 3 \\
\hline 44 & adapt instructional software to my curriculum needs & 1 & 2 & 3 \\
\hline 45 & write courseware for my own lessons & 1 & 2 & 3 \\
\hline
\end{tabular}

